\title{
Some Remarks on the Role of Tamil Literary Tradition in Śiva Śatakam of Nārāyaṇa Guru
}

\author{
Hanna Urbańska ${ }^{a}$
}

\begin{abstract}
The paper presents an analysis of the selected stanzas of Siva Śatakam (One Hundred Verses on Śiva)—the most important hymn devoted to Śiva composed in Malayalam by Nārāyaṇa Guru. The analysis shows that there is a tendency in the hymn to emphasise the equal status of Sanskrit and Dravidian literary tradition. Several stanzas are constructed on the basis of Sanskrit stories or myths; however, this "classical" scheme is filled with Tamil or Malayalam concepts, ideas, and key words. What is more, Nārāyaṇa Guru employs so called twilight language used by authors of Tamil philosophical works in order to provide a receiver of the poem with the opportunity to interpret some stanzas in accordance with Sanskrit as well as Dravidian tradition. The introduction of a person belonging to lower caste of South India as the one who is able to attain liberation, as well as presentation of the well-known philosophical concepts as equal or even subordinated to the Dravidian ideas could become a significant contribution to the social activity of Guru comprising among others the concern for spiritual and social uplift of the lower caste people of Kerala.
\end{abstract}

Keywords

Śiva Śatakam, Nārāyaṇa Guru, Tirumantiram, Kuṇḍlinī, Tamil literary tradition

In the present paper, an attempt will be made toward interpreting selected stanzas from the Malayalam work of Narayana Guru (Nārāyaṇa Guru, 1854-1928), a South Indian philosopher and social reformer from Kerala. In his poem Śiva Śatakam (abbr. ŚŚ)—One Hundred Verses on Siva, based on different philosophical systems (Śaiva Siddhānta, Yoga, Tantra, etc.), Narayana combines Sanskrit and Dravidian (Tamil and Malayalam) tradition ${ }^{1}$. The intent of the paper is to present the method of introduction of several Tamil ideas into a composition based on the "classical" Sanskrit scheme, attested by ancient Indian literary tradition. Narayana Guru was proficient-as well as in Malayalam and Sanskrit-in Tamil language and literature (Yati 2007: 13; Balachandran 2015: 20-21). He translated into Malayalam a part of Tirukkura! "without losing even a bit of its beauty in language and meaning and retaining its original style" (Balachandran 2015: 21) as well as Oliviloțukkam ${ }^{2}$; he also composed poems in Tamil (Tēvārappatikanika!-A Set of Verses on Adoration of Gods).

This might explain why the first stanza of Siva Śatakam contains an allusion to the Tamil work, although the plot of the story mentioned here is shared by both the Sanskrit and the Tamil tradition. It is the South Indian version of the famous epic Mahābhārata, from which Narayana Guru derived the motif of

aUniversity of Wrocław, Poland

Correspondent Author:

Hanna Urbańska, University of Wrocław, Pl. Uniwersytecki 1, 50-137 Wrocław, Poland 
writing down the poem, which was considered to be the fifth Veda $a^{3}$ by Ganeśa with his broken tusk on the slopes of the sacred Meru Mountain which served as a palm leaf. Two commentators, T. Bhāskaran and M. N. Prasād, quote the portion of the Tamil Villi Bhäratam which could be the literary source of the story included in the first stanza of ŚŚ:

As soon as the best of sages Vyāsa who was practicing penance-had composed Mahābhārata as the fifth $V \bar{e} d a$ - together with the four Védas existing in this world surrounded with the ocean, he had bowed to the God (Ganeśa), who wrote it down (using) the Meru Mountain as a palm leaf and his broken tusk as the pen ${ }^{4}$.

One can find a reference to that extraordinary writing material in the first stanza of ŚŚ: The slopes of (Meru) Mountain (adriyinmēl) serve as the palm leaf for Ganeśa, whereas the tip of his broken tusk becomes the pen (munikonbu):

In olden times, the Perfect-Eared One gracefully wrote down from end to end the story of Mahābhärata battle with (the tip) of his broken tusk on the slopes of (Meru) Mountain; may the divine form (of Lord) - the manifestation of the Fullness remaining the close friend to his humble devotees, bestow protecting cares on us!

In the subsequent stanza of ŚŚ, another reference to the Tamil literary tradition can be found: The four Vedas described here with the expression aruma_a - "the excellent mystery/secret" as well as param atu - "what is transcendent, highest, supreme", ascribed to Krșna Dvaipāyana Vyāsa according to Sanskrit tradition, have been chanted in the language of Valluvar (Va!luvar), the author of the famous Tamil poem Tirukkural (Tirukkura!) - thanks to the Speech Goddess Sarasvati (Sarasvatī) or Bharati (Bhāratī). It is worth emphasising here that the term mara denoting secret as well as Vedic texts is of Tamil origin. The name of Goddess has been explained by Prāsad in accordance with the context of that stanza: $b h \bar{a}$ means brightness, light, or splendour, whereas rati denotes an experience of bliss. The name Bhāratī can be associated with the disposition of attaining bliss within consciousness, knowledge, or light ${ }^{6}$. The second stanza of ŚŚ runs as follows:

"The four excellent Vedas, revealed in olden times, were granted as divided into (four) parts to the Rain-Cloud-Dark-Skinned One (i.e. Krș̣na Dvaipāyana Vyāsa); that supreme (Knowledge) was recited in the tongue of Valluvar ${ }^{7}$ - may the Goddess Bharati protect us eternally"!

In both stanzas given above, there is a tendency to equate Sanskrit works and Dravidian ones; firstly, in the stanza constituting the praise of Ganapati (Ganapati), Narayana Guru mentions the great epic (Mahäbhärata), regarded as the fifth Veda-but in its Tamil version; secondly, it has been emphasised in the stanza constituting the praise of Sarasvati that both the Sanskrit Vedas and the Tamil Tirukkural were revealed thanks to the Goddess of Speech-Sarasvati (Bharati); as a result, the position and value of both must be admitted to be the same ${ }^{8}$.

The very same importance of Sanskrit and Tamil literary tradition has been suggested by Guru not only at the level of literary tradition and mythological issues, but also from the philosophical as well as from the social perspective. Stanza 24th of ŚŚ, in which one can find the influence of Tamil tradition, seems to touch on the subject of liberation in the context of the social situation and reforms introduced by Guru. It is worth recalling here that ŚŚ was composed during Guru's stay in Tamil Nadu, at Marutvāmala, which was renowned for its medical herbs:

"At the mountain top, there are three remedial herbs, guarded on both sides by snake and tiger; the untouchable one, having attained and taken the half (of such a medicine), shines again. O my heart! May you grasp and taste (the same)"'?

The source of the allegory given above has been indicated by two commentators, T. Bhāskaran and M. N. Prasād, both of whom provide the Malayalam summary of a corresponding portion of the Tamil poem 
Nantanār Caritam, composed by Gopalākrșṇa Bhārati (1810-1896). It presents the story of a Śaivite devotee, belonging to the untouchable community (paraiyār), who finally become physically merged with Siva in a blaze of light: "On the theatrical stage of the great joy and the fullness of bliss, there is a remedial herb which can remove the confusion of mind. No other medicine can be useful for your mind". "My Lord, I am your slave"-in such words, Nantanār speaks to Brahmin, staying in his house in order to work; as soon as he-having taken pains-found snake and tiger, the agricultural work was completed. After the whole world was measured, both Viș̣n and Brahmā, having seen it, became filled with joy. Beautiful one, Goddess Pārvatī, has eaten one half of it. Another half has remained. Say, may I eat (such a half) as soon as I get (your) consent: "Come here and see"! "As soon as I get the approval, my illness will disappear" ${ }^{\prime 10}$.

The story given above has been adapted by Guru after several transformations have been introduced. Firstly, the animals (tiger and snake) imagined as an obstacle during agricultural work, became two custodians preventing an ascent to the mountain top, where three remedial herbs are mentioned as growing. The vision proposed by Guru is shared by both the Sanskrit and the Dravidian tradition. The concept of the divine herb, Soma, which can cure all diseases and which later becomes identified with the juice of immortality as well as with the Moon, is widely known in Indian tradition ${ }^{11}$ and obtains a particular meaning in Saivism: the top of mountain, interpreted here by commentators as Kailāsa peak, being the abode of Siva Himself, becomes crowned with the immortality-giving herb or juice. The concept of Soma, being identical to the mind and decorating Śiva's head at the same time, appears in ŚS $82-83^{12}$. When interpreted in the context of Kundaliñ Yoga, which is present in the South Indian Śaiva tradition-especially in Tirumantiram (abbr. TM) of Tirumūlar - as Śiva Yoga ${ }^{13}$, an ascent to the mountain top crowned with the immortality herb can symbolise the yogic experience, i.e. the ascent of the serpent power (Kundalinī śakti) within the central channel of the human body, called sușumnā (represented by Meru Mountain in Tirumantiram, whereas Kailāsa Mountain represents its top) in order to reach the top of the head ${ }^{14}$. The nectar or immortality juice (am $! a$ ) is described as flowing down from the moon region of the body, which comprises the head sphere containing energy centers (cakras) called ājñ̄a and sahasrāra, situated respectively between the eyebrows and on the top of the head ${ }^{15}$. Hence, the process of the ascension of Kundalinin sakti, finally reaching the top of the yogi's head, is symbolically described as the absorption of moon digits representing divine powers (śaktis) in the moon region of the body in order to compound the full moon. The concept is present in several stanzas of ŚŚ: the 83rd (the fullness of Soma symbolising the mind), the 78th (the moon or the mind fixed on Siva's head as opposed to the unstable mind of a devotee), the 28th, and the 35th (the expression mulumati denotes the perfect i.e. full moon as well as a perfect i.e. liberated mind).

The three remedial herbs mentioned in the stanza of ŚŚ quoted above are interpreted by T. Bhāskaran and J. B. Nāyar as sat, cit and $\bar{a} n a n d a^{16}$, i.e. they can symbolise the aspect of the ultimate reality having attributes (Saguna Brahman) or-in accordance with Śaiva Siddhānta, the leading philosophical system in ŚŚ-the aspect of Śiva having attributes or parts (Sakala Śiva). Accordingly, the snake can be interpreted as deeds (karman) or defilements (malarina!) binding the individual being, whereas the tiger denotes egotism (ahanta) ${ }^{17}$; ultimately the first animal can symbolise desire, whereas the tiger can denote anger or hatred ${ }^{18}$. There is another concept which has been suggested by Guru and which has been borrowed from a Tamil story: The man is said to eat half of the remedial herb, which is an allusion to the concept of Ardhanāriśvara (half-Śiva, half-Śakti, inseparably connected with Him) being one of the pivotal concepts of Śaivism; in another stanza of ŚŚ 
(ŚŚ 21), Narayana mentions a devotee who yearns for sharing the half of Śiva's body, just like Goddess shares the one half.

Another intriguing concept introduced by Guru has been associated with the term pulayan, which means untouchable one; a man belonging to the pulaya community; an out-caste. The term has been interpreted by T. Bhāskaran and M. N. Prasād as jñāni- "knowing (the higher or spiritual knowledge), liberated one (as a result of tasting remedial herbs)". Another explanation has been proposed by J. B. Nāyar-according to his interpretation, the term pulayan defines an individual being bounded by defilements (so an impure one)-jivian. We can refer at this moment to the Tamil source: Since this stanza is based on the story included in the poem by Gopalākrșṇa Bhārati, in which the devotee of Śiva is a man belonging to the untouchable caste, the original meaning of that term seems to be well-grounded. However, another possible interpretation has been proposed by M. N. Prasād: He brings our attention to the Tamil term pulavan, meaning "learned man". The context allows us to accept both interpretations.

It seems possible that the 24th stanza has been influenced not only by the Sanskrit concept (the divine herb Soma growing at the mountain top) and the Tamil poem (the motif of the remedial herb and two beasts becoming an obstacle to getting it, a devotee of Śiva); there is also a story from Guru's life that could contribute to the plot of that allegory. In Narayana Guru's house, there were many servants from the Pulaya community who worked in the fields. He became acquainted with a man from the Pulaya community named Cāttan. At one point, he came to know that Câttan has become a victim of leprosy. In those days, society used to alienate lepers. Narayana marched to the Pulaya's house to give him medicines and Cāttan was cured (Poojary 2014: 62-63). Narayana at that time went on with his research in the field of Ayurveda, immersed in the practice of medicines, agriculture, cattle grazing, reading, and studying. It was during this period that he spent more time on learning Tamil classics (Balachandran 2015: 20-21). Later, while working as a teacher, he could not teach children from the Nāyar or Pulaya castes, as according to tradition, it was not possible, so he started going to the Pulaya's streets to teach them (Poojary 2014: 64). Could that experience have influenced his heart and mind enough to treat it as an important step on his spiritual path ${ }^{19}$ ? If so, the 24 th stanza of ŚŚ can be considered as a particular combination of the Sanskrit, Tamil, and Malayalam traditions, successfully mingling philosophical, social, and literary issues in order to teach a lesson that can be comprehended differently according to the situation, the predispositions of the receiver, and so on. Let us recall the concept of Kundalini mentioned above, which could be the result of the influence of philosophical Tamil works like Tirumantiram. It is not only the concept itself, but also the style and language that Guru adopted in his poems. To express their mystical experience and to conceal the spiritual doctrines of Kundalini Yoga from the uninitiated, Tamil saints used a kind of paradoxical language called twilight language - - "clothed language in which the highest truths are hidden in the form of the lowest, the most sacred in the form of the most ordinary. The meaning of the poems operates at two levels - one, the exoteric and the linguistic, the other, the esoteric and the symbolical" (Ganapathy 2006a: 295-297). Let us make an attempt to interpret one of the stanzas which was influenced possibly by Tamil works - their style, language, and concepts. It is the 11th stanza, which has a particular position in ŚŚ, constituting part of a long and elaborate description of Śiva's body from the top of His head (stanza 7th) to His feet (stanza 17th). The previous 10th stanza depicts the Lord's face (his speech and glance), whereas the subsequent one (12th) - his neck and hands. The whole description has been composed in accordance with the rules of Sanskrit poetics: For example, Siva's nose has been compared to sesame blossom (as in Gitagovinda X 
$14)^{20}$; his teeth-to pearls, cheeks - to the full-moon ${ }^{21}$, etc. What is more, Narayana obeys the Sanskrit rule of grammatical gender agreement ${ }^{22}$. Among all these stanzas, the construction and intention of stanza 11th seems to be different. The stanza runs as follows:

"Moon-light, sprouting toward the fresh coral mountain, illuminating the whole surface of water-lily, embraces the stars-silver jewels; I pray with folded hands in order to achieve your protection/salvation ${ }^{23}$ ".

Since stanza 11th is preceded by the description of Siva's speech and glance and followed with stanza 12th depicting Siva's neck, the elements included within the passage quoted above can be interpreted accordingly, i.e. following the sequence of parts of the body being described by Guru: Water lily becomes a symbol of Śiva's face (Nāyar 2010: 215) and moon-light-Siva's smile (Jayakumar 1999: 212; Nāyar 2010: 215; Bhāskaran 2015: 169), whereas the coral hill denotes Śiva's lips (Nāyar 2010: 215) or his reddish matted hair (Prasād 2012: 56), and the stars-his eyes (Bhāskaran 2015: 169) or teeth (Nāyar 2010: 215). However, it is striking that no part of body is mentioned expressis verbis in this case. It gives us the possibility of interpreting stanza 11th in a different way, in the context of a yogic experience of Kundalin̄ Yoga. In such a case, the water-lily (kuvalaya) can be treated as a symbol of the lowest (root) energy center (cakra) in human body called mülādhāra cakra ${ }^{24}$, or possibly higher cakras. The fresh (i.e. ready to be mounted) coral hill can symbolise the serpent power (Kundalinī śakti) activated in the mūlädhära cakra ${ }^{25}$, the summit of the Meru Mountain, which stands for the central channel in the human body-sușumna ${ }^{26}$, the forehead (adorned with the brilliant light of the highest cakras-äjñā and sahasrāra) ${ }^{27}$, or the Kailāsa Mountain placed within (or symbolising) the highest cakra $(\text { sahasrāra })^{28}$. The sprouting moon-light denotes the sahasrära cakra situated within the moon region of the body (comprising the head sphere above $\bar{a} j \tilde{a} \bar{a}$ cakra placed between the eyebrows), or possibly the nectar (am!ta) flow released in the crown of the head $^{29}$; it can also symbolise two inner forces of nirvāna śakti-the sixteenth and seventeenth digit (kalā) of the moon, called respectively amā-kala and nirvāna-kalā. The first one is said to be placed in the moon sphere of the body, within the triangle symbolising the Kailāsa Mountain (placed within sahasrāra cakra), and described as being "as thin as the hundredth part of the lotus-fibre", lustrous, shaped like the crescent moon turned downward, discharging a stream of nectar. It is receptacle of the nectar that flows from the union of Śiva and Śakti. Amā-kalā is both looking towards creation and upwards or towards liberation; it takes the soul to liberation upwards. In the lap of this kalā, the nirvāna-kala is placed. It is more subtle and also turned downward, bestowing divine knowledge (Avalon 1950: 446-449, 457-458; Goswami 1999: 174). It is liberating śakti known also as am țākārarūpin̄i (having the nature and form of am lta or nectar), more excellent than amā-kalā. The famous ancient myth describing the churning of the milk ocean resulting in the nectar flow is presented by Narayana Guru in stanza 35th of ŚŚ, in which the concept of the churned depth of the ocean identified with the mind/moon (mati) appears. The expression "sprouting moon-light" (mulacce hlum nilāv) — toward the water-lily - when associated with the description of Siva's face and interpreted in the context of the second part of the stanza (the act of praying with folded hands for protection) - could also be an allusion to the concept of the sixth face turned downwards (adhomukha) by which Lord Siva looks upon the world with compassion ${ }^{30}$. The stars (tärarinia!), embraced by the moon-light, could be identified in such a case with all the powers (śaktis) residing in each cakra, described in TM 3662 as damsels joining their mother, divine grace (arul-śakti) seated in $\bar{a} j \tilde{n} \bar{a}$ cakra - or with all the powers (śaktis or kalās) existing in magnified form in sahasrāra cakra; when the yogi's awareness merges with Siva consciousness in the moon region of the head (candra 
mandala), the moon absorbs all his śaktis ${ }^{31}$.

In Table 1 given below, we present several possibilities of interpretation as regards separate elements of the description included in ŚŚ 11th.

To sum up, as regards its position within the passage depicting Śiva's body, stanza 11th can be interpreted as a metaphorical description of the elements of his face (eyes, lips, etc.); when treated as part of a poetic work influenced by the Tamil Śaivite tradition using twilight language, it can be interpreted as a metaphorical description of a mystical experience of Kuṇ̣̂alin̄̄ Yoga.

\section{CONCLUSIONS}

The question arises whether the combination of Sanskrit, Tamil, and Malayalam stories, motifs, and concepts made by Narayana Guru was a natural process, spontaneously attendant on the work of a Malayali learned man who was proficient in Sanskrit as well as Tamil language and literature. There is a tendency in the first two stanzas of ŚŚ to emphasise the equal status of Sanskrit and Dravidian literary traditions. This equality concerns the oldest Indian scriptures-sacred hymns of Vedas corresponding with the Tamil work of Valluvar, as well as later, epic literature represented by Mahäbhärata composed both in Sanskrit and Tamil language. In stanza 24th, Narayana Guru seems to use as simple and plain plot of story as possible in order to permit the receiver to interpret and complete it in accordance with both Sanskrit and Dravidian traditions; however, the key word, which defines the person who is able to obtain the knowledge as well as attain the liberation-pulayan, is of Malayalam origin. The motif of the divine remedial herb has been introduced into composition being the story of Saivite devotee, composed in Tamil language. Those who belong to Pulaya caste used to work in fields as farmers. Narayana has associated the story with the concept of ascent up the mountain top; the reason for such an association could be the influence of Tamil philosophical works like Tirumantiram, employing a so called twilight language to describe the mystic experience of Kundalini: In such case, an ascent up the mountain top means a climb of Kundalini sakti to the summit of a mountain representing sușumna $\bar{a}$ channel. It is intriguing that stanza 35th has been constructed by Guru in analogical way: the scheme of Sanskrit myth of the churning of the milk ocean has been used here in order to introduce the well-known in Śaiva and Tantra tradition concept of churning of the depth of mind (matiya $\underline{a}$ i); as a result, the devotee attains perfection, which causes the flow of immortality juice (am!ta) and the rise of the Sun being Consciousness-arkkabimbam ${ }^{32}$. Again, the key expression "the end of the flux (of phenomena)" -oliviloțukam-directs us to Tamil tradition; it is the title of the famous work comprising ideas of several non-dualistic philosophical systems. Without any doubt, the introduction of an out-caste person as the one who is able to taste the remedial herb and attain liberation, as well as presentation of the well-known philosophical concepts as equal or even subordinated to the Dravidian ideas could become a significant contribution to the social activity of Guru comprising among others the concern for spiritual and social uplift of the lower caste people of Kerala. The elaborate description of Śiva (stanzas from 7th to 17th) containing the enigmatic verse 11 th being the suggestion of a mystical yogic experience and the vision of the Lord extending his compassion, composed most likely under the influence of Tamil philosophical work - has its equivalent in the last part of ŚŚ (stanzas from 95th to the last one-100th), where Narayana mentions the head of Śiva decorated with Gamg $\bar{a}$ water representing the Lord's grace (aru!) and bringing immortality (amaravāhini) ${ }^{33}$. The introductory stanza of such a vision seems to be given earlier-It is stanza 84th constituting the description of Siva remaining motionless in Cidambaram, which means the space of the heart as well as the famous temple in Tamil Nadu. The Lord bestowing his grace 
Table 1. Possible Interpretations of the Expressions Included in Stanza 11th of Śiva Śatakam

\begin{tabular}{|c|c|c|c|}
\hline Kuvalayam-water lily & Puttan pavilamala-fresh coral hill & Nilāv-moon-light & $\begin{array}{l}\text { Venmañi tārakaninal-stars } \\
\text { being silvery pearls }\end{array}$ \\
\hline $\begin{array}{l}\text { Śiva's face (Nāyar); } \\
\text { earth (Bhāskaran) }\end{array}$ & $\begin{array}{l}\text { Śiva's lips (Nāyar); reddish matted } \\
\text { hair (Prasād) }\end{array}$ & $\begin{array}{l}\text { Śiva's smile (Jayakumar; } \\
\text { Nāyar; Bhāskaran) }\end{array}$ & $\begin{array}{l}\text { Śiva's eyes (Bhāskaran); Śiva's } \\
\text { teeth (Nāyar) }\end{array}$ \\
\hline $\begin{array}{l}\text { Mūlādhāra or higher } \\
\text { cakras: } \\
\bar{a} j \tilde{n} \bar{a}, \\
\text { indu, } \\
\text { or sahasrāra cakra }\end{array}$ & $\begin{array}{l}\text { Serpent power (Kuṇdalinī śakti) } \\
\text { awakened in mūlādhāra cakra; } \\
\text { the summit of Meru Mountain, which } \\
\text { symbolises the central channel } \\
\text { (sușumnā); } \\
\text { forehead (lalātạ) adorned with the } \\
\text { brilliant light of the highest cakras } \\
\text { (ājñā cakra or indu cakra situated } \\
\text { above, called also the soma or candra } \\
\text { cakra); } \\
\text { Kailāsa Mountain placed within (or } \\
\text { symbolising) the highest cakra } \\
\text { (sahasrāra) }\end{array}$ & $\begin{array}{l}\text { Sahasrāra cakra associated } \\
\text { with the moon region of the } \\
\text { body comprising the sphere } \\
\text { above ājñ̃a cakra (the head); } \\
\text { immortality nectar (am!ta) } \\
\text { released from the top of the } \\
\text { head; } \\
\text { Pati-jñāna-knowledge of } \\
\text { Siva, described in TM as a } \\
\text { silvery stream of am!̣ta; } \\
\text { amā-kalā/nirvāna-kalā } \\
{[\text { sixteenth or seventeenth }} \\
\text { digit (kalā) of the } \\
\text { moon]-both are situated } \\
\text { within Kailāsa in sahasrāra } \\
\text { cakra, described as } \\
\text { extremely subtle parts } \\
\text { bestowing divine knowledge } \\
\text { or nectar }\end{array}$ & $\begin{array}{l}\text { All the powers (śaktis) residing } \\
\text { in each cakra, joining their } \\
\text { mother, divine grace } \\
\text { (aruf-śakti) residing in } \overline{a j} \tilde{n} \bar{a} \\
\text { cakra; } \\
\text { digits or parts }(\text { kalā }) \text { residing in } \\
\text { sahasrāra cakra; when the } \\
\text { yogi's awareness merges with } \\
\text { Śiva consciousness in the moon } \\
\text { region of the head, the moon } \\
\text { absorbs all his śaktis }\end{array}$ \\
\hline
\end{tabular}

and compassion on devotees remains the Siva residing in the sacred space of Dravidian territory.

\section{Notes}

1. Śiva Śatakam-One Hundred Verses on Śiva - is the longest and the most important hymn devoted to Siva, composed by Guru around 1884 during his stay at Marutvāmala in Tamil Nadu.

2. Narayana studied among others Tirukku_a! by Va! huvar, Tiruvācakam by Mānikkavācakar, and Oliviloțkkam by Kaṇnuțaiyava!lalār.

3. Four Vedas constituting the collection of ancient Indian hymns are considered to be the oldest layer of Sanskrit literary tradition.

4. Kațal cū Lunna lōkatt unțāyirunna nālu vēdarinatôtoppam añcāmatte vēdamāyi mahābhāratam tapassurra munivaranāya vyāsan uraceytappō! mahāmēruparvatam èțāyum tante orrakkonb eluttāniyāyum tīrtta dēvane namaskarikkunnu [Bhāskaran, T. 2015. Śrīnārāyaṇaguruviṇ̃e Sampūrṇakritika! (The Complete Works of Sree Narayana Guru). Kozhikode: Mathrubhumi.
P. 164]. Comparing Prasād, S. M. N. 2012. Śivaśatakam, Nārāyaṇaguru (One Hundred Verses on Śiva of Narayana Guru). Varkala: Narayana Gurukula. P. 28 (kațal cūhunna lōkatt unțāyirunna nālu vēdariniậtoppam añcāmatte vēdamāyi mahābhāratam, munirājanāya vyāsan parañ̃̃u koțttappō! mahāmēruvine ētākkiyum tanı́e orrakonbine eluttāṇiyākkiyum koṇt atehutunna dēvane namaskariccu anpinuvēnți irakkunnu). Tamil literary sources are given in the Malayalam translation.

5. Alakoțu bhāratayuddhamadriyinmēl mu_uceviyanmurikonbukonțumunnam/e_hutini_acceliyōrkkin añni nilkkum muLumutalākiya mūrtti kāttukolka //1//.

6. Bhā ennāl prakāśam. rati ennāl ānandānubhavam. prakāśattil athavā añivil ānandam kanțtettunna svabhāvattōṭu kūṭiyatukoṇtān bhārati enna pēruṇtāyat [Prasād, S. M. N. 2012. Śivaśatakam, Nārāyaṇaguru (One Hundred Verses on Siva of Narayana Guru). Varkala: Narayana Gurukula. P. 33].

7. Arumạ̊anālumorikkalōtimunnam karimukilvarṇnanu pankuceytunalki/paramatuva!!hvarnāvilum

moliňňapparimalabhārati kāttuko!lka nityam //2//.

8. Samsk!̣tavēdavum tamilhvēdavum orē sarasvatiyil ninnudbhaviccatināl avayuțe mēnma samamtanne-_since 
both the Sanskrit Vedas and the Tamil Veda originated from Sarasvati, the position and value of both is one and the same" [Bhāskaran, T. 2015. Śrīnārāyaṇaguruvințe Sampūrnakritika! (The Complete Works of Sree Narayana Guru). Kozhikode: Mathrubhumi. P. 165].

9. Malayatiluṇtu marunnumūnnu pānbum puliyumatinnirupāțumuṇțāoval/pulayanețuttubhujiccupātiy innum vilasati nìyumețtutukolkaneňcē //24//.

10. Pērimbam, paripūrṇnānandam enna ararininulḷil cittabhramam māruvānu!̣a marunnirikkunnunțt. marru marunnuka!lkoṇt manassinu prayojanamilla. nātha, ñānarinayut ațimayāṇ -itu nantanār jōlikku ninnirunna vīț̣ile brāhmañanōtu parayunnatān - pāmbum puliyum valare panippețtu tirakkikkanțtetti krși ceytețttatān at. lōkam muhuvan alanna viṣnuvum brahmāvum atu kaṇtu santōṣiccu. Pārvvati ennoru sundari atil pāti tinnu. iniyum pāti irikkunnu. paraya, nīyum pōy nōkkuka ennuttaravu tannālum. à uttaravu kițtiyāl ente rōgam māñum [Bhāskaran, T. 2015. Śrīnārāyaṇaguruviṇ̌e Sampūrnakritika! (The Complete Works of Sree Narayana Guru). Kozhikode: Mathrubhumi. P. 176]. Comparing Prasād, S. M. N. 2012. Śivaśatakam, Nārāyaṇaguru (One Hundred Verses on Siva of Narayana Guru). Varkala: Narayana Gurukula. P. 91.

11. The concept of Soma - a heavenly herb growing at the top of the mountain, appears in Rgveda-the collection of ancient Indian hymns being the oldest layer of Sanskrit literature. Soma has been identified with the moon and am rta (immortality juice) in later texts.

12. "Soma (the moon) that rose in the pond of flourishing water-lilies, by spreading out his rays, happened to become the charioteer of Eros (i.e. Kāma), the flower-darted one. Somehow he lost his brilliance, and with feet immersed in darkness is still undergoing penance, having become fully lost in it (82). Do you feel in your gentle mind that as the growth of kālas (digits) become complete, his final merger will occur? Anyway, let him not suffer any more, being seated at the head of the enemy of Eros that you are (83)"- transl. by Prasād, S. M. N. 2006. Narayana Guru. Complete Works. New Delhi: National Book Trust. P. 47. The Soma (moon) denotes also a mind immersed in primeval darkness (ignorance), still practicing penance; the final merger - after completing all the digits-can symbolise the process of attaining liberation [comparing Nāyar, J. B. 2010. Śrīnārāyaṇa Gurudēvakntika!. Sampūrṇa Vyākhyānam (Works of Sree Narayana Guru With Complete Interpretation). Thiruvananthapuram: The State Institute of Languages. Vol. 1. Pp. 264-266].

13. The Tantric concept of Kundalinī, a serpent power which is coiled at the base of the spine in a state of sleep, and - when awakened - rises up within the central channel of the body (sușumnā), opening six energy centers (cakras) in order to reach the top of the head where the last cakra (sahasrāra) is situated, has been adopted into the South Indian Śaiva Siddhānta system mainly through the Tamil work Tirumantiram by Tirumūlar, who according to Tamil tradition was born in Tamil Nadu and travelled to Kailāsa. $\mathrm{He}$ is considered to be one of the first saints to bring the Tantra aspect of Śaivism from Kashmir to the Tamil world [Tagare, G. V. 2001. Śaivism. Some Glimpses. New Delhi: D. K. Printworld (P) Ltd. P. 60]. The Śaivism of Tirumūlar comprises Kuṇdalin̄̄ Yoga, although Tirumūlar calls it Siva Yoga (Ganapathy, T. N. 2006b. "The Yoga of Tirumandiram." Pp.157-241 in The Yoga of Siddha Tirumular. Essays on the Tirumandiram, edited by T. N. Ganapathy, K. R. Arumugam, and G. Anand. Quebec: Babaji's Kriya Yoga and Publications).

14. Comparing TM 82455 (Śakti or Kuṇdalinī unites the Meru Mountain which represents Śiva); TM 82640 (Meru represents the sușumna channel); TM 41112 (Śakti is a flower twig on the top of Meru representing sușumna channel); TM 3625 (the mystic mountain represents sahasrāra); TM 1246 (the Mountain Meru represents the suṣumnā channel; Kailāsa represents sahasrāra; nectar flows in the moon-space).

15. The whole body is believed to be a conglomerate of parts (kalās) or powers (śaktis). The highest part of human body - the head-is called the moon region (candra maṇala). When Kundalin̄ śakti reaches the moon region at the ajjñ $\bar{a}$ cakra, one assimilates the moon's lustre and its coolness. A bright light shines in the centre of the eyebrow and the whole front of the forehead becomes illuminated. Blending with the sixteen kalās or the divisions of the moon, the seeker is said to become the moon itself (TM 3 685; 669).

16. Satt, citt, ānandam enna mūnn aușadharinia! irippunt_- "there are three remedial herbs called sat, cit and ānanda" [Nāyar, J. B. 2010. Śrīnārāyaṇa Gurudēvakntika!. Sampūrṇa Vyākhyānam (Works of Sree Narayan Guru With Complete Interpretation). Thiruvananthapuram: The State Institute of Languages. Vol. 1. P. 224]; similarly Bhāskaran, T. 2015. Śīnārāyaṇaguruviň̨e Sampūrṇakritika! (The Complete Works of Sree Narayana Guru). Kozhikode: Mathrubhumi. P. 175.

17. Sañcitam, āgāmi, prārabdham ennī karmmariniậ, àṇavam, karmmam, māya enn̄̄ malaninạ̄ō àyirikkum pānb, puli ahantayum - "snake denotes deeds - stacked up deed, deed having future effects, done with deed-eventually three defilements (ānavam, karmmam, māya); tiger symbolizes egotism" [Bhāskaran, T. 2015. Śrīnārāyaṇaguruviṇ̂e 
Sampürnakritika! (The Complete Works of Sree Narayana Guru). Kozhikode: Mathrubhumi. P. 175].

18. Rāgamākunna pānbum dvēșamākunna puliyum — "snake being desire and tiger representing anger and hatred" [Nāyar, J. B. 2010. Śrīnārāyaṇa Gurudēvakntika!. Sampūrṇa Vyākhyānam (Works of Sree Narayana Guru With Complete Interpretation). Thiruvananthapuram: The State Institute of Languages. Vol. 1. P. 224].

19. It is said that after Narayana had seen so many miseries, he rejected worldly life and decided to become an ascetic (saminyāsin). Poojary, B. S. 2014. Shree Narayana Guru Vijaya Darshana (English translation by B. Shashilekha). New Delhi: The Billawara Association. P. 64.

20. Dinamanitinkalaniňn̆

kannurantum maṇimayakuṇdalakarṇnayugmavum

tē/kanakatilakkusumam kuniňňukūppiddinamanu sēvaka! ceytitunna mūkkum //8// ("The sun and the moon ornamentally forming the two eyes of yours, the two ears adorned with gem-made earrings; the charming nose before which golden sesame flowers bow low in all humility and perform daily personal service-to perceive all this straightaway is what I yearn for"- transl. by M. N. Prasād. Prasād, S. M. N. 2006. Narayana Guru. Complete Works. New Delhi: National Book Trust. P. 27).

21. Palavinayokkeya[nuttițunna tonțippalamoțu pōriletirttițnna cunțum/ kalukiyețttoru muttotottapallum mu_hmatipōle kavilttațininahum tē //9// ("While cutting asunder all my harmful latent impressions of the past, your lips constantly fight in beauty with the reddish tondi berry; you rows of teeth, that resemble well-cleansed pearls, the full-moon-like cheeks as well-to perceive all this straightaway is what I yearn for"- transl. by M. N. Prasād. Prasād, S. M. N. 2006. Narayana Guru. Complete Works. New Delhi: National Book Trust. P. 27).

22. Comparing ŚS 14 , in which the line of hair above the navel (Sanskrit compound rōmarāji) of feminine gender has been compared to the kalindakanya (Malayalam compound borrowed from Sanskrit)-rising up daughter of Kalinda Mountain (i.e. the river Yamunā).

23. Kuvalayamokke vilaninitunna puttan pavilamalaykku mulaccęum nilāvum/tąhvina veṇmaṇi tārakaninahum ninno_ivare rakșaka! ceyyuvān toLhnnēn //11//.

24. Mūlädhära is the lowest cakra situated near the coccygeal plexus beneath the sacrumit; the higher cakras are: svādhișthāna, located two finger-widths above, manipūra being behind the navel, anähata which is the heart cakra, viśuddha-the throat cakra, ajjĩ $\bar{a}$ located in the space between the eyebrows, and sahasrāra above the top of the head. As soon as the awakened Kundalinī reaches the last cakra, the individual being attains liberation.
25. The activated Kundalini power is described in TM-in the section devoted to adhomukha - as a fire of a reddish (coral) hue, that is identical to the Lord (TM 2 520-523).

26. The image of a sacred mountain representing the sușumna channel has been associated in Kundalini Yoga with the well-known myth of the churning of the ocean of milk for the recovery of am!ta (TM 3 625). Mandara (Meru) Mountain stands for the central channel (TM 3 672).

27. Tirumūlar mentions the Lord in the form of a brilliant light dispelling darkness (over the mount), interpreted by Ganapathy as the forehead decorated with the light of cakra situated in the space between the eyebrows-ajjñ $\bar{a}$ cakra (TM 9 2694).

28. Kailāsa mountain as an abode of Śiva in the Laya Yoga system is said to be situated in the form of a triangle within the highest cakra situated above the top of the head-sahasrāra, the moon region, or represents sahasrāra itself [Avalon, A. 1950. The Serpent Power Being the Shat-Chakra-Nirūpana and Pādukā-Panchakā. Madras: Ganesh and Co. (Madras) Ltd. Pp. 149-153].

29. In TM, sahasrāra cakra is called nilä-mandala-"the moon-light region" (Ganapathy, T. N. 2006b. "The Yoga of Tirumandiram." Pp. 157-241 in The Yoga of Siddha Tirumular. Essays on the Tirumandiram, edited by T. N. Ganapathy, K. R. Arumugam, and G. Anand. Quebec: Babaji's Kriya Yoga and Publications. P. 174). Nectar is produced by the union of Siva and Śakti, and runs in a stream from the top of the head (brahmarandhra) to the mūlādhāra cakra [Avalon, A. 1950. The Serpent Power Being the Shat-Chakra-Nirūpana and Pādukā-Panchakā. Madras: Ganesh and Co. (Madras) Ltd. P. 484].

30. When the Lord acts to redeem souls, He acts through adhomukha (TM 2 520-525). Yogis would say that when Kuṇulinī śakti is awakened and rises from the mūlädhāra, it rises up to join Lord Śiva at the crown cakra, sahasrāra. The compassionate energy of the Lord manifests itself through adhomukha, the downward looking face. The union of the two bindus, red in the sun at mūlādhāra, and white in the moon at the head, could be referred in Tirumantiram (TM 3 728). It is worth emphasizing here that amā-kala mentioned above has also the aspect called adhomukhi- - "downward-turned-mouthed".

31. The stars can be interpreted as the illusory brightness of worldly life, which enslaves countless souls (TM 3 860-862). However, in this case, the term seems to refer to the object of positive meaning, as it has been associated with the verb talukuka - "to caress, embrace" and with the silver colour (venmani) representing the moon region. The connection between the two words suggesting protection can be found here: tārakarinal (stars - carrying across; protectors) and raksaka!(protection/salvation—plural form). 
32. Toliluka!̣n̆cumoliňňu tōnni nilkkum mu_hmatiyālika tạñneț̣ttumunnam/ohuki varunnam !̣unțtumāṇtupōkāt oluviloțukkamudikkumarkkabimbam //35//.

33. The waves of river Gamiga flowing from Śiva's head can symbolize the process of manifestation of the phenomenal world as well as the flow of the prāna or am țta (as soon as the individual being attains self-realization, the stream of am rta is said to be released at the top of the head).

\section{References}

Avalon, A. 1950. The Serpent Power Being the Shat-Chakra-Nirūpana and Pādukā-Panchakā. Madras: Ganesh and Co. (Madras) Ltd.

Balachandran, M. 2015. Sree Narayana Guru-A Comprehensive Study. Varkala: Sivagiri Madam Publications.

Bhāskaran, T. 2015. Śrīnārāyaṇaguruviṇ̄e Sampūrṇakritika! (The Complete Works of Sree Narayana Guru). Kozhikode: Mathrubhumi.

Ganapathy, T. N. (ed. and trans.), T. V. Venkataraman (trans.), T. N. Ramachandran (trans.), and K. R. Arumugam (trans.). 2010. The Tirumandiram. Translation and Commentary. Vol. 10 Quebec: Babaji's Kriya Yoga and Publications.

Ganapathy, T. N. 2006a. "The Twilight Language of the Tirumandiram." Pp. 295-338 in The Yoga of Siddha Tirumular. Essays on the Tirumandiram, edited by T. N. Ganapathy, K. R. Arumugam, and G. Anand. Quebec: Babaji's Kriya Yoga and Publications.

- 2006b. "The Yoga of Tirumandiram." Pp. 157-241 in The Yoga of Siddha Tirumular. Essays on the
Tirumandiram, edited by T. N. Ganapathy, K. R. Arumugam, and G. Anand. Quebec: Babaji's Kriya Yoga and Publications.

Goswami, S. S. 1999. Layayoga. The Definite Guide to the Chakras and Kundalini. Vermont: Inner Traditions.

Jayakumar, V. 1999. Sree Narayana Guru. A Critical Study. New Delhi: D.K. Printworld (P) Ltd.

Nāyar, J. B. 2010. Śrīnārāyaṇa Gurudēvakntika!. Sampūrṇa Vyākhyānam (Works of Sree Narayana Guru With Complete Interpretation). Thiruvananthapuram: The State Institute of Languages.

Poojary, B. S. 2014. Shree Narayana Guru Vijaya Darshana (English translation by B. Shashilekha). New Delhi: The Billawara Association.

Prasād, S. M. N. 2006. Narayana Guru. Complete Works. New Delhi: National Book Trust.

—_. 2012. Śivaśatakam, Nārāyaṇaguru (One Hundred Verses on Śiva of Narayana Guru). Varkala: Narayana Gurukula.

Tagare, G. V. 2001. Śaivism. Some Glimpses. New Delhi: D. K. Printworld (P) Ltd.

Yati, N. C. 2007. Narayana Guru. New Delhi: Indian Council of Philosophical Research.

\section{Bio}

Hanna Urbańska, Ph.D., associated professor, Indian Philology and the Culture of India, Institute of Classics, Mediterranean and Oriental Studies, University of Wrocław, Poland; research fields: ancient Indian fable, Indian philosophy, Malayalam literature, philosophical and religious systems of Narayana Guru. 